\title{
大倉集古館創建時図面の調査
}

\section{THE STUDY ON HISTORIC DRAWINGS ABOUT OKURA MUSEUM OF ART}

\section{杉江夏呼}

キーワード :

伊東忠太，大倉喜八郎，図面，大倉土木，歴史的建造物

Keywords:

Chuta Ito, Kihachiro Okura, Drawings, Okura Doboku Corporation, Historic architecture

\section{Natsuko SUGIE}

The study describes an analysis on historic drawings about OKURA MUSEUM OF ART designed by Chuta Ito. There are 43 drawings, these drawings are original drawings, blue prints, microfilms. Only one sheet of drawing has a signature by Chuta Ito. 14 architectural drawings have a common title block. These are the final drawings. There were somehow related to Chuta, and definitely or probably designed by Chuta. These 14 final drawings are not a reduced scale. So it is impossible to build the museum building with these final drawings. I assume there was a backup by Okura Doboku in the construction.

\section{1. 研究の背景・既往研究・目的}

大倉集古館建屋は、伊東忠太設計 - 大倉土木株式会社（現大成建 設）施工により、1927年11月竣工した。2013年時点の外観を写真 1 に示す。付属の管理事務所を仮移転した2015年に、大倉集古館建設 時の創建時図面が発見された。大倉集古館の創建時図面は、作品集 ${ }^{11}$ 建築雑誌2)「財団法人大倉集古館、祇園閣、京都大倉別邸建築記念寫 眞帖」 ${ }^{3)}$ に掲載されているものが数枚ある ${ }^{(11)}$ 。また大成建設に創建時 図面が21枚残されていることを、著者が報告している4)。大倉集古館 建屋の図面に関寸るこれまでの研究を顧みると、倉方俊輔の論文5) 7) や拙稿 ${ }^{4) 8)}$ があるが、今回発見の創建時図面は対象にしていない。 大倉集古館建屋は1998年に国の登録有形文化財となり、その文化財 価值が認められた昭和初期の貴重な美術館建築である。本稿の目的 は、価值の高い大倉集古館建屋の創建時図面資料を調查することに よって、伊東忠太の行った設計内容と経緯、大倉土木との協働を明 らかにすることである。大倉集古館建屋と同時期に建設された祇園 閣図面のうち、大成建設所蔵注2) 創建時図面82枚については、前稿9) において伊東忠太自筆図の特徵をいくつか指摘した注 3$)$ 。本稿におい ても同様の視点で大倉集古館の創建時図面を対象に調查を行い、更 に祇園閣図面と比較考察を行う。伊東忠太の設計活動に関する研究 を更に進める上で、これらの成果は意義があると考える。

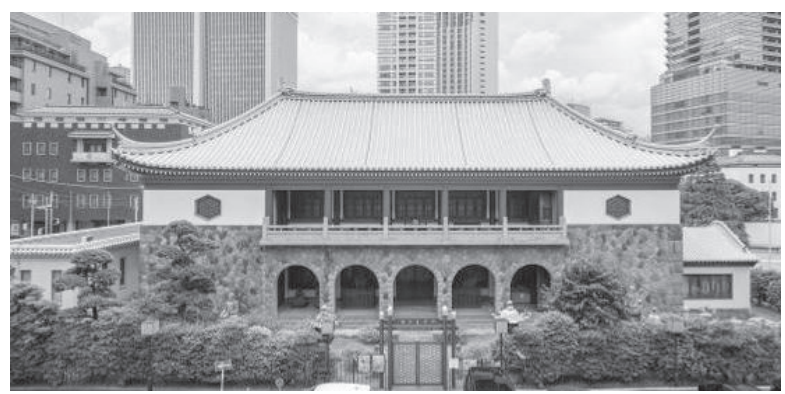

写真1 外観（2013年）

\section{2 大倉集古館の建設経緯・建物概要・沿革}

大倉集古館は日本初の私立美術館といわれる。大倉土木など数々 の企業の創立者である大倉喜八郎 $(1837 \sim 1928)$ にり設立された。 大倉喜八郎は 50 余年にわたって蒐集した多数の文化財、土地、建物 を寄付し、1917 年 8 月財団法人大倉集古館が誕生した。しかし 1923 年関東大震災により、当初の建物と陳列中の所蔵品を失った。幸い 倉庫は無事であったため、伊東忠太設計による耐震耐火の陳列館を

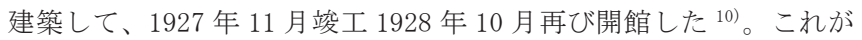
現大倉集古館建屋である。第二次世界大戦中には幸い空襲の難を免 れた。記念写真帖 ${ }^{3)}$ に記載された建物概要の抜粋を以下に示す。 所 在 地: 東京市赤坂區葵町三番地（現 東京都港区虎ノ門 2-10-3) 建 築 年: 起工、大正十五年 (1926) 一月二十日

竣工、昭和二年 (1927) 十一月二日

設 計 者: 伊東忠太博士 施工 者 : 大倉土木株式会社

構造概要 : 本建築は耐震耐火性とし、主要軸部を鉄筋コンクリート 造、屋上小屋組は鉄骨造とする。

様式: 支那風注）上記（）内は著者による追記。 1962 年ホテルオークラ建設に伴い、大倉集古館の付属棟（写真 2 手前に写る別館・渡り廊下・六角堂）が撤去された。

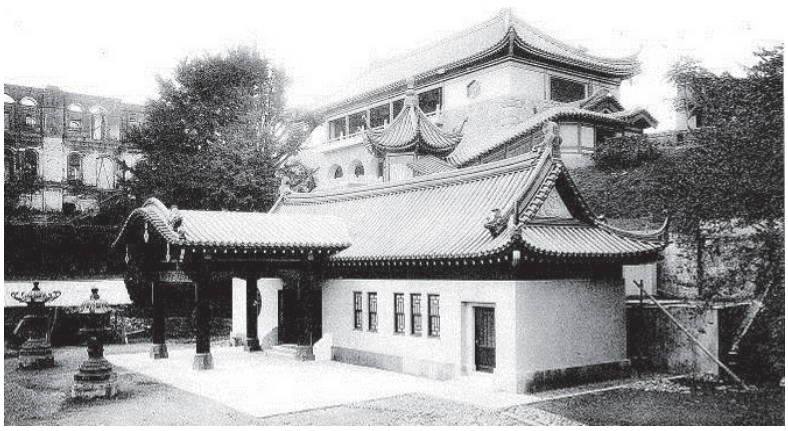

写真 2 外観（1927 竣工時）

本稿は 2015 年度日本建築学会大会 (関東) で発表したもの ${ }^{4)}$ に追加・加筆した。 大成建設一級建築士事務所 博士 (工学) TAISEI DESIGN PLANNERS ARCHITECTS \& ENGINEERS, Dr. Eng. 


\section{3 設計者伊東忠太と施主大倉喜八郎の関わり}

伊東忠太と大倉喜八郎の関わりは、1912年に始まったと言われる。 大倉喜八郎が向島別邸建設に当たって、片山東熊や妻木頼黄、伊東 忠太に建物の相談したことが契機となった ${ }^{11)}$ 。伊東忠太が設計を行 った大倉喜八郎関連の物件は、大倉集古館と同時期に建設された祇 園閣や京都大倉別邸など8件であり、そのうち4件が建設された4)。 護国寺にある喜八郎の墓も伊東忠太の設計によるものである。大倉 集古館は中国風の独特な意匠から、伊東忠太の東洋建築に関するう んちくを引き出した作品と言われる。また伊東忠太の伝記をまとめ た建築家岸田日出刀は、大倉集古館について「建物と作者がとがピ ッタリ合つた、この作者にしてこの作ありの感を深ふするやうな建 築である。」と述べている ${ }^{12)}$ 。

\section{4 創建時図面概要と調査内容}

大倉集古館から新たに発見された創建時図面は、3つの図面綴り とバラの青焼き図面である。3つの図面綴りの内容は「市街地建築 物法に基づく建築申請書の添付図」「大倉集古館建築図」「市街地 建築物法に基づく変更申請書添付図」であった（写真 3 ）。バラの 青焼き図は 3 つの図面綴りと重複が多く、重複していない図面は 9 枚だった。既報告 ${ }^{4)}$ の大成建設所蔵 21 枚とも内容を確認したところ 大成建設のみが所蔵する図面が 2 枚あった。これら創建時図面のリ ストを表 1 に示す。大倉集古館所蔵図面はケント紙に描かれた原図 が 2 枚（いずれも設備図）、他は全て青焼き図、大成建設所蔵図面 はマイクロフィルムである。本稿では内容を見やすくするため、青 焼き図の白黒を反転して掲載する。図面の調査は、作図年月日、忠 太印や署名の有無、図面枠や筆致などに注目して行う。
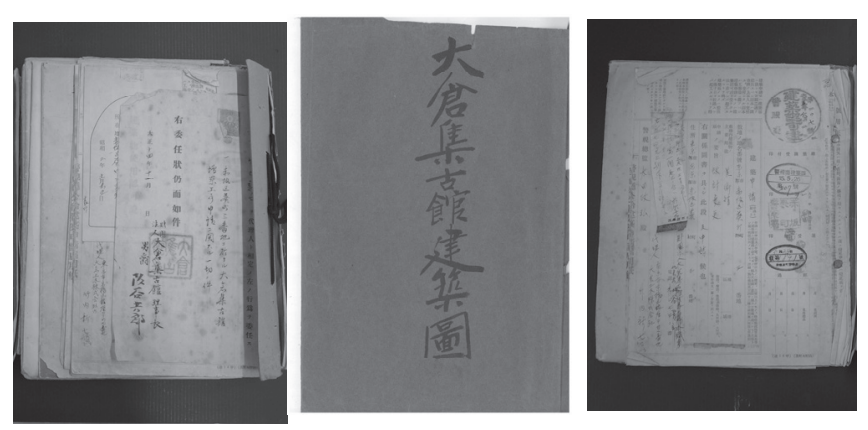

写真 3 左「市街地建築物法に基づく建築申請書」つづり 中央「大倉集古館建築図」つづり 右「市街地建築物法に基づく変更申請書」つづり

\section{1 「市街地建築物法に基づく建築申請書の添付図」}

図面枚数 11 枚（表 1 No1 11）

建築許可証の発行日は大正 15 （1926）年 1 月 9 日である。表書き 申請書に記載されている設計者名は大倉土木株式会社建築部で、伊 東忠太ではない。表書き申請書に続き、青焼き図面が折込まれて経 じ紐でまとめられている。各図面は、図面の裏に「3 平面㘠」のよ うに通し番号と図面名が文字書きされ、図面の表に図面と図面名が 書かれている。表側の図面名には記載がないものもある。添付図の 1 枚目は「1 参考立面図」（図 1 ）で、作図年月が大正十四年五月 と記載がある。この「1 参考立面図」は、作図年月の記載がある全
5 枚の中で最も古い。調查対象図面の中で唯一「工学博士伊東忠太 考案」の記載があり（図１１）、伊東忠太の関与は明らかである。 前稿 ${ }^{9)}$ で確認した伊東忠太自筆図面と共通の特徵は、記名以外に人 物が描かれている（図1の(2)-1, (2)-2) ことである。

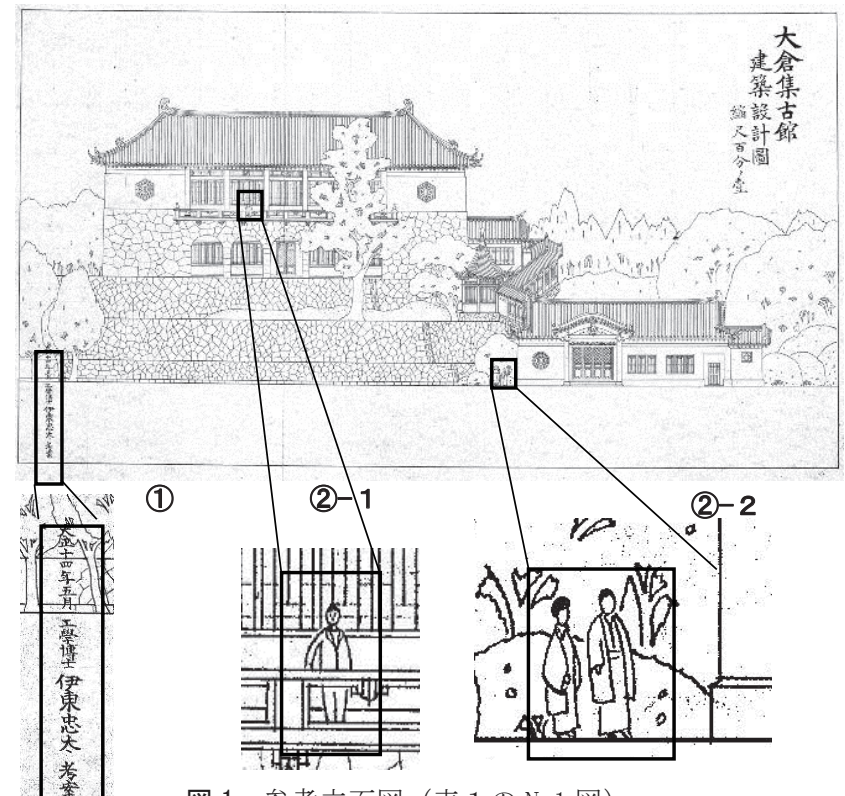

図 1 参考立面図（表 1 の No1 図）

この図面は伊東忠太自筆の可能性があると考え、作品集 ${ }^{1)}$ の他の自 筆図面と比較した。作品集に大倉集古館図面 2 枚が掲載されている が、いずれも自筆図でない。作品集に掲載されている伊東忠太自筆 図面は 18 枚あり、そのうち 16 枚は立面図（平面図併記含む）だっ た。16 枚全てにスケールバーの記載があり、15 枚に人物の記載があ る。図 1 は人物の記載はあるがスケールバーは記入されておらず、 筆致も他の自筆図と異なることから、伊東忠太の関与は明らかであ るものの、自筆図ではないと考えた。

\section{2 「大倉集古館建築図」図面枚数 18 枚（表 1 No12～29）}

「大倉集古館建築図」の表紙の次に、青焼き図面が折込まれて綴 じ紐でまとめられている。10枚の意匠図と8枚の構造図からなる一綴 りの図面である。日付の記載のあるものは 1 枚（表 1 No22別館各側 竪壁配筋図）のみで、その日付は「15.3.1」とあり、前述工期によ ると既に施工期間中である。意匠図10枚全てに、60mm角の図面タイ トル枠が書かれている。図面タイトルは縦に 5 行、右から物件名（大 倉集古館) ・図面名・縮尺が記入されている。8枚は構造図で、大倉 土木の図面タイトル枠又は図面枠なしに書かれている。これら $2 つ$ の図面タイトル枠を図 2 に示寸。構造図の図面タイトル枠は、祇園閣 で使用されたものと同じだった。意匠図面10枚には、寸法記入が全 くない。縮尺が記入されているので、スケールを当てれば大まかな 寸法は分かるが、この図面に基づき施工することは困難である。ま た施工会社の大倉土木が、寸法記入のない施工困難な図面を作成す るとは考えにくい。寸法記入のないことから設計初期段階の図面と も思われたが、縮尺 $1 / 2$ の詳細デザイン図などあり、更にそのデザイ ンは現建物に近いものが多い（図 3 )。これら図面は、むしろ設計後 期の図面之考えられる。また屋根の飾り金物や階段手寸りの狛犬な 
表 1 大倉集古館現建屋創建時図面一覧

*)記名はないが伊東忠太の関与図と判断した図面

\begin{tabular}{|c|c|c|c|c|c|c|c|c|c|}
\hline & & No & 年月日 & $\begin{array}{l}\text { 図面名称 } \\
\text { 【】 内は図面名称の記載がない場合の图面内容 } \\
\text { （）内は图面裏に記諓された图面タイトル }\end{array}$ & 縮尺 & 図面枠 & $\begin{array}{l}\text { 伊東忠太の関 } \\
\text { 与を示す記載 }\end{array}$ & $\begin{array}{l}\text { 寸法 } \\
\text { 記入 }\end{array}$ & 備考 \\
\hline \multirow{7}{*}{\begin{tabular}{l}
1 \\
\multicolumn{1}{c}{${ }^{\text {市 }}$} \\
街 \\
地 \\
建 \\
築 \\
物 \\
法基 \\
にづ建 \\
<築 \\
申 \\
請 \\
届 \\
書
\end{tabular}} & \multirow{11}{*}{$\begin{array}{l}\text { 建 } \\
\text { 築 } \\
\text { 許 } \\
\text { 可 } \\
\text { 證 } \\
\text { 大 } \\
\text { 正 } \\
+ \\
\text { 五 } \\
\text { 年 } \\
- \\
\text { 月 } \\
\text { 九 } \\
\text { 日 }\end{array}$} & 1 & $\begin{array}{l}\text { 大正十四年 } \\
\text { 五月 } \\
\end{array}$ & 大倉集古館建築設計図（1参考立面圖 1/100） & $\begin{array}{l}\text { 縮尺百 } \\
\text { 分ノ壹 }\end{array}$ & なし & $\begin{array}{ll}\text { 工学博士 } \\
\text { 伊東忠太考案 } \\
\end{array}$ & なし & 人物、植栽の記載あり \\
\hline & & 2 & なし & 大倉集古館建物配置図（2配置圖） & $1 / 300$ & なし & なし & なし & 新築部分、焼跡保存部分、焼跡取除キ部分の記載あり \\
\hline & & 3 & なし & $\begin{array}{l}\text { 【全体の平面図と建築敷地高低表示図】（3 平面 } \\
\text { 図） }\end{array}$ & なし & なし & なし & あり & 人物の記載あり \\
\hline & & 4 & なし & 基礎圖（4 基礎平面図） & $1 / 100$ & なし & なし & あり & \\
\hline & & 5 & なし & $\begin{array}{l}\text { 【西面と東面が半分ずつ書かれた立面図、1／4程 } \\
\text { 度が断面図になっている南立面図】（5 本館立面 } \\
\text { 圖 1/50) }\end{array}$ & なし & なし & なし & あり & 地盤面からの床高、軒高などの記載あり \\
\hline & & 6 & なし & 別館立面図（6別館立面圖） & $1 / 50$ & 大倉土木 & なし & なし & 別館立面図と平面図が記載。 \\
\hline & & 7 & なし & $\begin{array}{l}\text { 【六角堂と渡り廊下の立面図、断面図】 } \\
\text { ( } 7 \text { 亭及渡り廊下 } 1 / 100)\end{array}$ & なし & なし & なし & あり & \\
\hline \multirow{4}{*}{$\begin{array}{l}\text { 添 } \\
\text { 付 } \\
\text { 図 }\end{array}$} & & 8 & なし & 【本館小屋組】（8 本館小屋組詳細図 1/20) & なし & なし & なし & あり & \\
\hline & & 9 & なし & 【配筋図】(9 本館柱梁基礎及天井版配筋図 1/20) & なし & なし & なし & あり & \\
\hline & & 10 & なし & $\begin{array}{l}\text { 【本館二階床版配筋図】（10 本館二階床版配筋図 } \\
1 / 20 ）\end{array}$ & なし & なし & なし & あり & \\
\hline & & 11 & なし & $\begin{array}{l}\text { 【別館の矩計に配筋鉄骨を記入したもの】（11 別 } \\
\text { 館詳細図 } 1 / 20 ）\end{array}$ & なし & なし & なし & あり & \\
\hline \multirow{18}{*}{$\begin{array}{l}\text { 大 } \\
\text { 倉 } \\
\text { 集 } \\
\text { 古 } \\
\text { 館 } \\
\text { 築 } \\
\text { 龱 }\end{array}$} & & 12 & なし & 大倉集古館·立面圖 & $1 / 100$ & 正方形 & なし* & なし & \\
\hline & & 13 & なし & 大倉集古館·平面圖 & $1 / 100$ & 正方形 & なし* & なし & 作品集・建築雃誌・記念寫尰帖掲載図、スケールバーあり \\
\hline & & 14 & なし & 大倉集古館別館立面圖 & $1 / 100$ & 正方形 & なし* & なし & \\
\hline & & 15 & なし & 大倉集古館別館車奇及玄関詳細圖 & $1 / 20,10$ & 正方形 & なし* & なし & 建築雑誌掲載図、動物モチーフの詳細あり \\
\hline & & 16 & なし & 大倉集古館六角堂詳細圖 & $1 / 20,1,5$ & 正方形 & なし* & なし & 動物モチーフの詳細あり \\
\hline & & 17 & なし & 大倉集古館本館立面圖 & $1 / 50$ & 正方形 & なし* & なし & \\
\hline & & 18 & なし & 大倉集古館本館室内詳細圖 & $1 / 20,5$ & 正方形 & なし* & なし & 建築雑誌掲載図、動物モチーフの詳細あり \\
\hline & & 19 & なし & 大倉集古館本館階段室詳細圖 & $1 / 20,10$ & 正方形 & なし* & なし & 動物モチーフの詳細あり \\
\hline & & 20 & なし & 大倉集古館本館二階望椽詳細圖 & $1 / 10$ & 正方形 & なし* & なし & \\
\hline & & 21 & なし & 大倉集古館本館屋根詳細圖 & $1 / 20,2$ & 正方形 & なし* & なし & 動物モチーフの詳細あり \\
\hline & & 22 & 15.3 .1 & 大倉集古館別館各側㹂壁配筋図 & $1 / 50$ & 大倉土木 & なし & あり & \\
\hline & & 23 & なし & (別館床スラブ、基礎配筋図) & なし & 大倉土木 & なし & あり & \\
\hline & & 24 & なし & 柱及び壁配筋図 & なし & なし & なし & あり & 六角堂の図面 \\
\hline & & 25 & なし & 本館正面広間間仕切矩計 & $1 / 10$ & 大倉土木 & なし & あり & \\
\hline & & 26 & なし & 本館柱鉄筋詳細圖 & $1 / 30$ & なし & なし & あり & \\
\hline & & 27 & なし & (階段配筋図) & なし & なし & なし & あり & \\
\hline & & 28 & なし & 集古館本館隅小屋詳細図 & なし & なし & なし & あり & \\
\hline & & 29 & なし & 屋根小屋詳細 & $1 / 10$ & なし & なし & あり & \\
\hline \multirow{5}{*}{$\begin{array}{c}3 \\
\text { 物申 } \\
\text { 法請 } \\
\text { 届 } \\
\text { 変添 } \\
\text { 更付 } \\
\text { 図 }\end{array}$} & 大+ & 30 & なし & 屋根小屋詳細(本館小屋組変更図) & $1 / 10$ & なし & なし & あり & 「朱書ノ通リ訂正ス」と書き込みあり。№30 図に赤で訂正 \\
\hline & 正五 & 31 & なし & 小屋受水平トラス詳細図 (本館小屋受水平トラス) & なし & なし & なし & あり & \\
\hline & 年 & 32 & なし & 別館小屋組変更図 (別館小屋受変更図) & $1 / 10$ & なし & なし & あり & 「朱書ノ通り訂正ス」と書き込みあり。 \\
\hline & 六 & 計算書 1 & なし & 大倉集古館新築工事設計変更申請書添付計算書 & なし & 大倉土木 & なし & - & 8 ページの計算書 \\
\hline & $\begin{array}{l}\text { 月 } \\
\text { 二 }\end{array}$ & 計算書 2 & $\begin{array}{l}\text { 大正十四・ } \\
+\cdot \text { 中四 }\end{array}$ & 大倉集古館計算書 & なし & 大倉土木 & なし & - & 26 ページの計算書 \\
\hline \multirow{9}{*}{$\begin{array}{l}4 \\
\text { バ } \\
\text { ラ } \\
\text { 図 } \\
\text { 面 }\end{array}$} & & 33 & $\begin{array}{l}\text { 大正十四年 } \\
+ \text { 十月 }\end{array}$ & 大倉集古館敷地排水設備配置図 & $1 / 300$ & なし & なし & なし & 申請図の配置図に排水設備を記入している \\
\hline & & 34 & なし & 大倉集古館建築平面圖 & $1 / 100$ & なし & なし & あり & 本館陳列室が 3 室に分けられている \\
\hline & & 35 & なし & 大倉集古館・立面圖 & なし & なし & なし & なし & \\
\hline & & 36 & なし & 本館壁鉄筋図 & $1 / 50$ & なし & なし & あり & \\
\hline & & 37 & なし & 大倉集古館別館入母屋詳細図 & $1 / 10$ & 正方形 & なし* & なし & 動物モチーフの詳細あり \\
\hline & & 38 & なし & 大倉集古館本館正面詳細図 & $1 / 20$ & 正方形 & なし* & なし & \\
\hline & & 39 & なし & 大倉集古館車寄破風詳細図 & $1 / 10$ & 正方形 & なし* & なし & 動物モチーフの詳細あり \\
\hline & & 40 & $\begin{array}{l}\text { 昭和二年十 } \\
\text { 二月 }\end{array}$ & 大倉集古館各種配線配管図 & $1 / 300$ & なし & なし & なし & $\begin{array}{l}\text { ケント紙にインンキングされた原図 } \\
\text { 配置図に設備が書き込まれている }\end{array}$ \\
\hline & & 41 & なし & 大倉集古館電気配線図 & $1 / 100$ & なし & なし & なし & $\begin{array}{l}\text { ケント紙にインキングされた原図 } \\
\text { 平面図に電気設備が書き込まれている }\end{array}$ \\
\hline \multirow{2}{*}{$\begin{aligned} \text { 5大成 } \\
\text { 所藏 } \\
\end{aligned}$} & & 42 & なし & 大倉集古館電燈器具詳細図 & $1 / 5$ & 正方形 & なし* & なし & \\
\hline & & 43 & なし & 本館矩計図 & なし & なし & なし & あり & \\
\hline
\end{tabular}

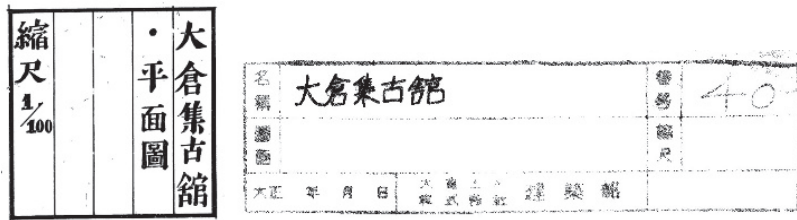

図2図面タイトル枠 (左・意匠図、右・構造図)
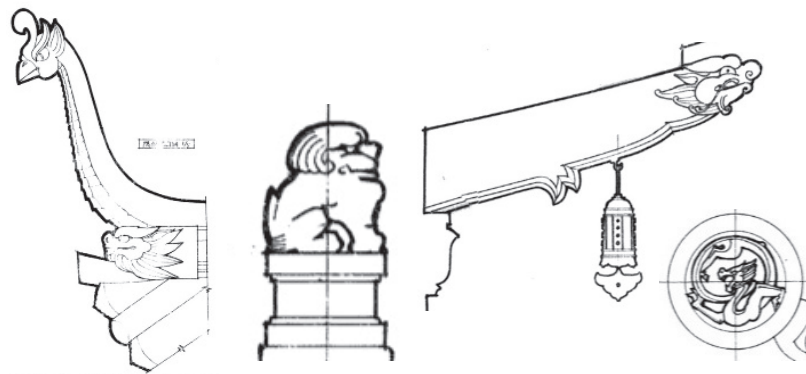

図4動物をモチーフにした詳細図（抜粋）

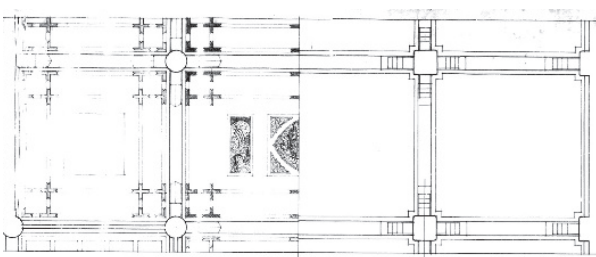

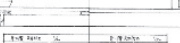

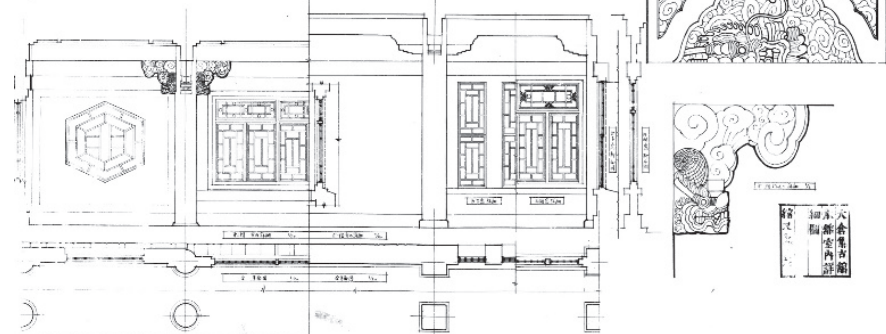

図 $360 \mathrm{~mm}$ 角の図面タイトル枠の意匠図面 (表 1 No18 大倉集古館本館室内詳細図) 
ど伊東忠太らしい動物をモチーフにした詳細図が多くある（図４）。 $60 \mathrm{~mm}$ 角の図面タイトル枠の意匠図は、図面内容と筆致から、伊東忠 太関与の意匠設計図と判断した。これら寸法のない意匠設計図面を 具現化するために、大倉土木の設計・施工両部門のバックアップが あったことは想像に難くない。

\section{3 「市街地建築物法に基づく変更申請書の添付図」}

図面枚数 3 枚（表 1 No30 32)

建築許可証の発行日は大正 15 (1926) 年 6 月 2 日である。表書き 変更申請書の次に、青焼き図面が折込まれて緅じ鋲でまとめられて いる。変更は全て構造図で、構造図に朱書きで訂正部が記入されて いる。訂正後の構造計算書 8 ページ（日付は大正 14 年 10 月 24 日） と訂正前の計算書 26 ページも添付されていた。計算書はいずれも大 倉土木の記名があり、構造設計は大倉土木が担当していた。

4.4 バラ図 図面枚数 9 枚（表 1 No33 41）

図面9枚のうち3枚には、60mm角の図面タイトル枠が書かれている。 表 1 No12から21の意匠図と一連の図面と考えられることから、伊東 忠太関与の意匠設計図と判断した。表 1 No36の大倉集古館敷地排水 設備配置図（日付は大正14年11月）は、表 1 No2の配置図に排水設備 を記入したものである。また原図が2枚、ケント紙に書かれた設備図 がある。表 1 No 37 の平面図は、図面内容から検討過程の平面図と考 えられる。

\section{5 大成建設所蔵図面 図面枚数 2 枚（表 1 No $40 \cdot 41 ）$}

図面 2 枚のうち 1 枚には、 $60 \mathrm{~mm}$ 角の図面タイトル枠が書かれてお り、上記と同様に伊東忠太関与の意匠設計図と判断した。この 1 枚 の図面は大倉集古館にはなく、大成建設にのみ保管されていた。No41 本館矩計図には、張石・シャッターボックス・シャッター操作ボッ クスそれぞれと躯体の関係が表現されており、施工中に書かれたも のと考えられる。

\section{5 祇園閣図面との比較}

大倉集古館と祇園閣は同じ施主・設計者・施工者で、ほぼ同時期 に実施されたプロジェクトだった洋)。竣工写真帖も「財団法人大倉 集古館、祇園閣、京都大倉別邸建築記念寫䢐帖」3) という名称で、1 冊にまとめられおり関係が深い。写真帖には設計者・施工者の記載 があるが、大倉集古館と祇園閣では内容が異なる。大倉集古館にお いて「設計 工学博士伊東忠太」「施工 大倉土木株式会社」、祇 園閣においては「設計及監督 工学博士伊東忠太」「製図及施工 大 倉土木株式会社」である。それを裏付けるように、祇園閣の意匠設 計図は大倉土木図面枠に書かれた一式が残されていた ${ }^{9)}$ 。一方大倉集 古館図面では大倉土木図面枠の意匠設計図面はなく、伊東忠太が関 与した意匠設計図面があった。祇園閣図面ではその詳細デザイン画 において、伊東忠太と大倉土木建築部が何度もやりとりをし、確認 しながら詳細デザインを仕上げる経緯が読み取れたが、大倉集古館 罒面にはそのやりとりは残されていない。その理由のひとつとして、 建設地が東京と京都で異なることがあげられるだろう。設計者・施 工者・建設地が東京である大倉集古館の工事において、伊東忠太が 現場に出向き施工担当者に直接指示寸る機会は多かったはずである。 一方祇園閣工事では直接指示できない代わりに図面によって指示さ れ、その経緯が図面に多く残されたのではないだろうか。

\section{6 まとめ}

本研究は、大倉集古館の創建時図面対象に行なった調查報告であ る。創建時図面は43枚あり、そのうち伊東忠太の関わりが明確に記 された図面は1枚だった。その 1 枚以外では、60 $\mathrm{mm}$ 角の図面タイトル 枠の意匠図面14枚（大倉集古館所蔵13枚大成建設所蔵1枚）に伊東忠 太の関与があったと考えた。この14枚全てに共通で、寸法記入が全 くない。寸法のない意匠設計図面を具現化するために、大倉土木の バックアップがあったと考えられる。また構造設計は大倉土木が行 い、市街地建築物法に基づく建築申請書に記入された申請者名も大 倉土木であることを確認した。

\section{謝辞}

本研究にあたり公益財団法人大倉文化財団大崎磐夫特別顧問に、 聞き取り調査にご協力いただいた。大倉集古館学芸員三島知美様に は資料分類にご協力いただいた。深く御礼申し上げます。

注

注 1）大倉集古館の創建時図面は、伊東博士作品集 ${ }^{1}{ }^{1}$ に平面図と立面図の 2 枚 が、当時の建築雑誌 2) に作品集と同じ平面図と立面図、加えて本館室内詳 細図と別館車寄及玄関詳細図の 4 枚が掲載されている。また記念写真帖 $\left.{ }^{3}\right)$ にも作品集と建築雑誌と同じ平面図が掲載されている。

注 2) 祇園閣の現在の所有者は創建時とは異なっており、現所有者は創建時祇 園閣図面を所有していないことをヒアリングにて確認した。

注 3) 祇園閣図面全 82 枚のうち 7 枚を伊東忠太自筆図と考えた根拠は、(1)作 品集に自筆図として掲載(2)工学博士伊東忠太考案等の書き込み(3)忠太印(4) 筆致(5)スケールバー記入 (6)人物の記載だった。

注 4）工事期間は、祇園閣 : 起工大正 15 年 7 月 5 日、竣工昭和 2 年 12 月 10 日、大倉集古館: 起工大正 15 年 1 月 20 日、竣工昭和 2 年 11 月 2 日。

\section{参考文献}

1）倉方俊輔監修：写真集成 近代日本の建築 14 （伊東博士作品集刊行編： 伊東忠太建築作品集, 城南書院, 1941 を収録），ゆまに書房,2014

2)大倉集古館巻末付図, 建築雑誌第 42 巻第 508 号, 日本建築学会, 1928.4

3) 大倉土木株式会社: 財団法人大合集古館、祇園閣、京都大倉別邸建築記念 寫眞帖, 1927

4)杉江夏呼 : 大成建設設計部所藏「伊東忠太設計の大倉喜八郎関連図面」そ の 1 概要,日本建築学会大会（関東）梗概集, 2015.9

5）倉方俊輔：伊東忠太の大正 - 昭和期における図面史料の考察 大正 $\cdot$ 昭和 期の図面類にみる伊東忠太の設計活動 その 1 , 日本建築学会計画系論文集, 第 578 号, 2004.4

6)倉方俊輔 : 伊東忠太の最初期の創作活動について-明治期の図面類に見る伊 東忠太の設計活動その 1 , 日本建築学会計画系論文集,第 558 号, 2002.8

7)倉方俊輔 : 伊東忠太の西本願寺関連の計画について-明治期の図面類に見る 伊東忠太の設計活動その 2 , 日本建築学会計画系論文集,第 566 号, 2003.4

8）杉江夏呼,堀米純子 : 大成建設設計部所蔵「伊東忠太設計大倉集古館三層閣 及廊図面」,日本建築学会大会 (九州) 梗概集, 2016

9)杉江夏呼: 大成建設設計部所蔵「伊東忠太設計祇園閣図面」, 日本建築学 会技術報告集,第 22 巻 第 51 号, pp. 783-788,2016.6

10）財団法人大倉文化財団 : 大倉集古館の名品, 2012.12

11）鈴木博之編：伊東忠太を知っていますか,王国社,2003.4

12）岸田日出刀：建築学者伊東忠太,乾元社, 1945

[2017 年 6 月 7 日原稿受理 2017 年 12 月 5 日採用決定］ 